\title{
A 28-fold increase in secretory protein synthesis is associated with DNA puff activity in the salivary gland of Bradysia hygida (Diptera, Sciaridae)
}

J.C. de-Almeida

\section{Correspondence}

J.C. de-Almeida

Departamento de Morfologia

Faculdade de Medicina de

Ribeirão Preto, USP

14049-900 Ribeirão Preto, SP

Brasil

Fax: 55 (016) 633-1786

Research supported by FAPESP (Nos. 92/5037-1 and 94/5790-7), CNPq (Nos. 30070088-1 and 401080/92-7), FAEPA and Alexander von Humboldt-Stiftung.

Received June 21, 1996 Accepted February 26, 1997
Departamento de Morfologia, Faculdade de Medicina de Ribeirão Preto, Universidade de São Paulo, 14049-900 Ribeirão Preto, SP, Brasil

\begin{abstract}
When the first group of DNA puffs is active in the salivary gland regions $\mathrm{S} 1$ and $\mathrm{S} 3$ of Bradysia hygida larvae, there is a large increase in the production and secretion of new salivary proteins demonstrable by $\left[{ }^{3} \mathrm{H}\right]$-Leu incorporation. The present study shows that protein separation by SDS-PAGE and detection by fluorography demonstrated that these polypeptides range in molecular mass from about 23 to $100 \mathrm{kDa}$. Furthermore, these proteins were synthesized mainly in the $\mathrm{S} 1$ and $\mathrm{S} 3$ salivary gland regions where the DNA puffs C7, C5, C4 and $\mathrm{B} 10$ are conspicuous, while in the $\mathrm{S} 2$ region protein synthesis was very low. Others have shown that the extent of amplification for DNA sequences that code for mRNA in the DNA puffs C4 and B10 was about 22 and 10 times, respectively. The present data for this group of DNA puffs are consistent with the proposition that gene amplification is necessary to provide some cells with additional gene copies for the production of massive amounts of proteins within a short period of time (Spradling AC and Mahowald AP (1980) Proceedings of the National Academy of Sciences, USA, 77: 1096-1100).
\end{abstract}

\section{Introduction}

Gene amplification for protein-coding genes during development has been demonstrated in only two biological systems: the DNA puffs of Sciaridae (1) and the chorion genes in ovarian follicle cells of Drosophila (2). In Drosophila the amplification of the chorion genes is followed by $5 \mathrm{~h}$ of intense protein production during which the endochorion and exochorion are synthesized. In the female-sterile Drosophila mutant ocelliless, in which two of these genes are amplified less, the corresponding mRNA and
Key words

- Gene amplification

- Secretory polypeptide synthesis

- DNA puffs

- Salivary glands of Sciaridae protein products accumulate at lower levels in the egg chamber. These results led Spradling and Mahowald (2) to propose that gene amplification is necessary to provide some cells with additional gene copies for the production of massive amounts of protein within a short period of time.

In the DNA puffs of Sciaridae, gene amplification was first quantified in Rhynchosciara americana, with the DNA being amplified 16 times for puffs $\mathrm{C} 3$ and $\mathrm{C} 8(3,4)$. A similar level of amplification was found in the puff II/9 of Sciara coprophila (5). The extent of amplification of the DNA puffs $\mathrm{C} 4$ 
and B10 of Bradysia hygida was established to be about 22 and 10 times, respectively, for DNA sequences that code for mRNA (6-9). There is evidence indicating that DNA puff activity is involved in the production of specific proteins in the salivary glands of Rhynchosciara americana (10-13), Bradysia hygida (14) and Trichosia pubescens (15), some of them being secretory proteins $(9,11,12$, 16,17).

However, an association between DNA puff activity and short periods of very large production of proteins, as shown for the chorion genes in Drosophila, has not been demonstrated for Sciaridae.

In the present study we showed a strong temporal correlation between the activity of the first four DNA puffs of Bradysia hygida and a short period of about $10 \mathrm{~h}$ of intense secretory protein synthesis. We also showed that some of the major polypeptides present in the saliva produced during this period were synthesized mainly in the salivary gland regions S1 and S3 where the first group of DNA puffs develops but were missing or only present as very faint bands in the S2 region where these DNA puffs do not develop.

\section{Material and Methods}

Animals

Bradysia hygida(18) is maintained in the laboratory at $20^{\circ} \mathrm{C}$, and under these conditions its life cycle lasts about 36 days. From hatching to the pupal molt the larvae go through four instars. The last instar begins on the 12th day after hatching, and at the 6th day of the 4th instar the eyespots arise and serve as useful age landmarks (19). The present experiments were carried out on female 4th instar larvae. A pair of salivary glands, about $10 \mathrm{~mm}$ long, is characteristic of larvae at the end of the 4th instar. The glands consist of two rows of cells and three morphologically distinct regions can be noted: S1 (anterior), S2 (granulosa) and S3 (posterior). About 190 cells form each gland $(20,21)$, and about 45 of them are in the S1 region.

The eyespot pattern E3 (8th day of 4th instar) coincides with the beginning of the DNA puff anlage formation. Eighteen hours later (eyespot pattern E5), the first group of DNA puffs starts its expansion (DNA puffs C7, C5 and C4). After $2 \mathrm{~h}$ the E7 pattern is attained and the 3 puffs are at least partially open, and about $8 \mathrm{~h}$ later all puffs have receded. The expansion of the 2 nd group of DNA puffs starts about $12 \mathrm{~h}$ after eyespot pattern E7, and before the pupal molt (about $26 \mathrm{~h}$ after E7) these puffs are already closed, with the exception of puff B3d. The DNA puff B10 is the only one active between the periods of expansion of the 1st and 2nd groups of DNA puffs. Its maximum size is attained at $\mathrm{E} 7+8 \mathrm{~h}$. The DNA puffs are present in the $\mathrm{S} 1$ and $\mathrm{S} 3$ regions, with the DNA puff $\mathrm{C} 7$ being exclusive for $\mathrm{S} 1$. The first group of DNA puffs does not form in the S2 region, and the puffs of the second group are very inconspicuous in this gland region.

\section{Protein labelling}

In all experiments $1 \mu \mathrm{l}$ of a solution of tritiated leucine $\left(\left[{ }^{3} \mathrm{H}\right]-\mathrm{Leu}\right)$ from Amersham $(159 \mathrm{Ci} / \mathrm{mmol})$ was injected into the larval hemolymph as described by Sauaia et al. (22).

\section{Saliva collection for radioactivity measurements or electrophoretic analysis}

Since during part of the period studied the larvae were still defecating, the last segment of the larvae was tied with a very small piece of hair under the stereomicroscope to avoid contamination of saliva with feces.

For radioactivity measurements (Figure 1), saliva was collected as follows: groups of two larvae were injected with $1 \mu \mathrm{l}$ of $\left[{ }^{3} \mathrm{H}\right]-$ Leu solution, and 5 min later they were 


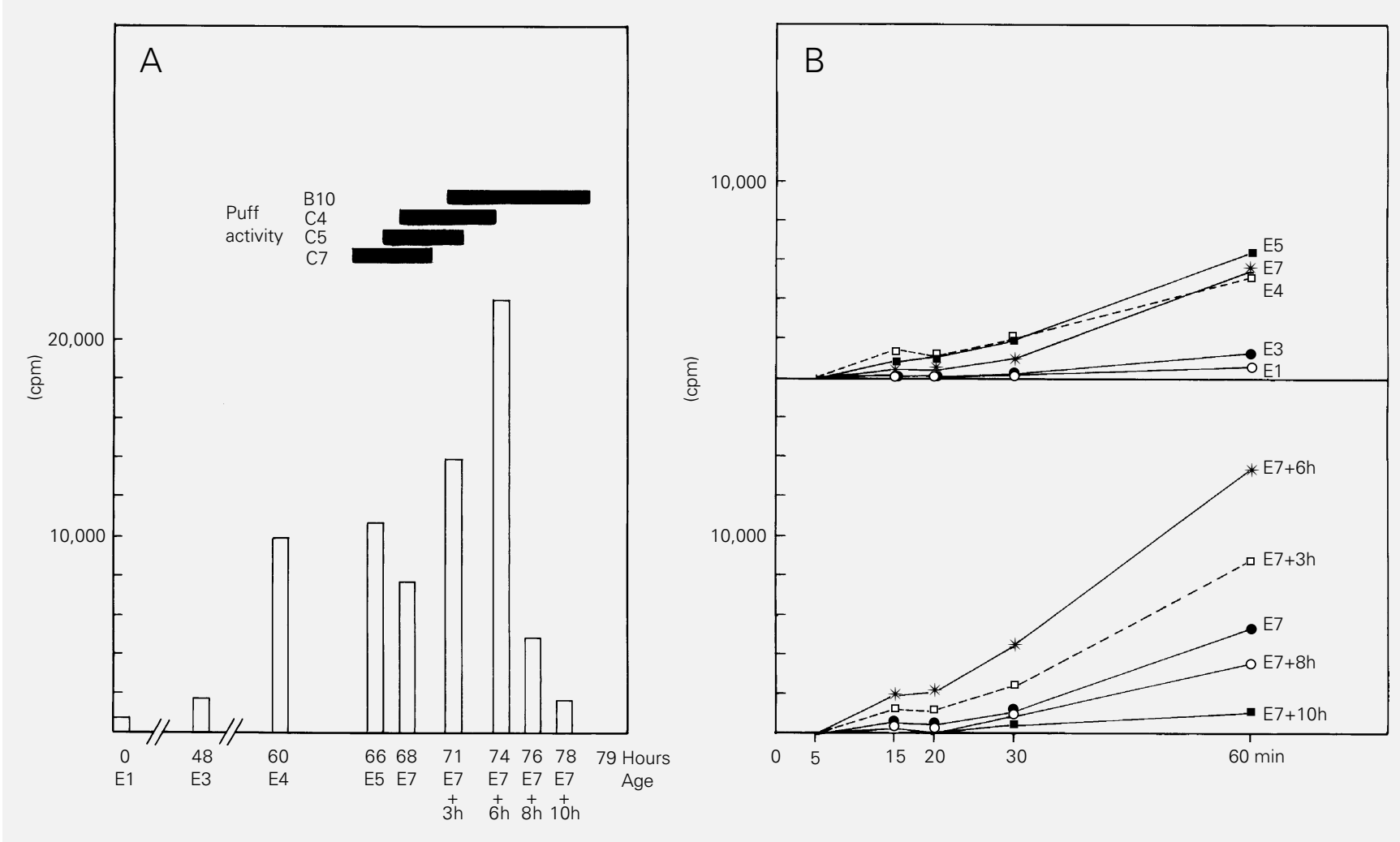

Figure 1 - Secretion of radioactive protein as a function of larval age. The radioactive protein was collected over a period of $1 \mathrm{~h}$ after the injection of $1 \mu \mathrm{l}$ of $\left[{ }^{3} \mathrm{H}\right]$-Leu solution into larvae at different ages (E1 to $\left.E 7+10 \mathrm{~h}\right)$. The radioactive material was collected on fiberglass filters at 5 to $15 \mathrm{~min}, 15$ to 20 min, 20 to $30 \mathrm{~min}$ and 30 to $60 \mathrm{~min}$ after injection of the radioactive precursor. The horizontal bars in Figure $1 \mathrm{~A}$ (top) show the times during larval development when DNA puffs are expanded. The cumulative radioactive secretion obtained during a period of $1 \mathrm{~h}$ is reported at the bottom as a function of larval age. The ages of larvae are expressed on the abscissa as hours from the first age studied and as eyespot patterns. Figure 1B shows the kinetics of secretion for the same experiments. Each result, in cpm, is the mean of 3 independent experiments.

placed on a moist circular fiberglass filter inside a scintillation vial. The larvae were maintained on the filter for $10 \mathrm{~min}$ and transferred to a second filter for $5 \mathrm{~min}$, to a third filter for $10 \mathrm{~min}$ and finally to a 4th filter for $30 \mathrm{~min}$. The larvae were then discarded and the filters were washed with $10 \%$ TCA $(3 \mathrm{x}$ $3 \mathrm{ml}$ ) and with $10 \mathrm{ml}$ ethanol. The filters were dried for $2 \mathrm{~h}$ at $80^{\circ} \mathrm{C}, 3 \mathrm{ml}$ of scintillation solution $(0.6 \%$ PPO in toluene) was added to each vial and radioactivity was measured with a Beckmann LS1801 Liquid Scintillation System. Three independent experiments were carried out and the results are reported as the means (Figure 1B). The cumulative amount of radioactivity during 60 min corresponds to the total radioactive material collected on filters $1+2+3+4$ in the same experiments (Figure 1A).

For electrophoretic analysis, saliva was collected as follows: after $\left[{ }^{3} \mathrm{H}\right]$-Leu injection, 4 larvae were placed at the bottom of an Eppendorf tube, the tube was closed and the larvae discarded $2 \mathrm{~h}$ later. The moist secretion was dissolved in $40 \mu \mathrm{l}$ of sample buffer (23). Since part of the secretion remains on the larval body, this method was used only for qualitative analysis by SDS-PAGE.

\section{Salivary gland samples for electrophoretic analysis}

Fifteen minutes after $\left[{ }^{3} \mathrm{H}\right]$-Leu injection the larvae were dissected and the salivary glands fixed in $70 \%$ ethanol for $30 \mathrm{~min}$ at room temperature. The glands were sepa- 
rated into their different regions $\mathrm{S} 1, \mathrm{~S} 2$ and S3 by dissection (22) and at least 6 regions were dissolved in sample buffer $(5 \mu \mathrm{l} / \mathrm{re}$ gion) and kept at $-20^{\circ} \mathrm{C}$ until the time for application to a gel.

\section{SDS-PAGE}

The polypeptides were separated on SDSpolyacrylamide (10\%) slab gels, $220 \mathrm{x} 120 \mathrm{x}$ $1 \mathrm{~mm}$, according to Laemmli (23). The gels were fixed and stained in methanol:water: acetic acid (5:5:2) + 0.1\% Coomassie brilliant blue for $2 \mathrm{~h}$ and destained overnight in $7 \%$ acetic acid. Alternatively, a fast destaining method was used, consisting of 3 washes (15 min each) in ethanol:water:acetic acid $(3: 7: 2)$.

\section{Fluorography}

The Coomassie-stained gels were treated for $20 \mathrm{~min}$ with glacial acetic acid, for 20 min with 20\% PPO in glacial acetic acid and for $30 \mathrm{~min}$ with several changes of water (24). The gels were dried and exposed to a preflashed X-Omat AR-5 Kodak film at $-70^{\circ} \mathrm{C}$.

\section{Results}

\section{Protein secretion as a function of larval age}

The protein nature of the labelled material was demonstrated by the fact that more than $99 \%$ of the radioactivity secreted by the larvae onto fiberglass filters was released by overnight treatment with $0.1 \%$ proteinase $\mathrm{K}$ (data not shown).

In order to compare the production of secretory proteins before, during and after the onset of the first group of DNA puff activity, larvae of 9 different ages were selected: E1, E3, E4, E5, E7, E7+3h, E7+6h, $\mathrm{E} 7+8 \mathrm{~h}$ and $\mathrm{E} 7+10 \mathrm{~h}$. The saliva was collected and radioactivity was measured as described in Material and Methods. Figure
1A (top) shows the time during larval development when DNA puffs C7, C5, C4 and B10 are active. Note that the initiation of puff expansion started $65 \mathrm{~h}$ after age E1 and that the initiation and duration of each puff were different during the 15 -h period of puff activity. Most of the cumulative secretion of tritium-labelled protein occurred during the period of puff activity with the exception of the 60-h point (age E4) which preceded puff activity (Figure 1A, bottom). Thus, at age E3 when the larvae are "walking around", before starting to build the individual cocoon, the amount of secreted material was only 2.2 times the amount secreted by larvae at the end of the feeding period E1. The eyespot pattern E3 was attained about $48 \mathrm{~h}$ after E1. About $12 \mathrm{~h}$ $(\mathrm{E} 1+60 \mathrm{~h})$ later the E4 pattern was established, after 5 to $6 \mathrm{~h}$ the larvae were at E5 (E1+65-66h), and the E7 pattern was reached about $2 \mathrm{~h}(\mathrm{E} 1+68 \mathrm{~h})$ later. At E4, E5 and E7, when the larvae were actively spinning their cocoon the amount secreted was $12.8,13.8$ and 9.9 times higher, respectively, than at $\mathrm{E} 1$. At E7+3h $(\mathrm{E} 1+71 \mathrm{~h})$, the collected radioactive material was 17.9 times at $\mathrm{E} 1$ and at $\mathrm{E} 7+6 \mathrm{~h}(\mathrm{E} 1+74 \mathrm{~h})$ a maximum activity of 28.5 times the amount of protein secreted during the end of the feeding period was attained. AtE7+8h and E7+10h (E1+76h and E1+78h) the amount secreted decreased to 6.2 and 2.1 times, respectively. At this time all DNA puffs but one (B10) in the 1st group had already receded.

The kinetics of the secretion at different periods of development is shown in Figure 1B. The top part of Figure 1B shows that ages E4, E5 and E7 had the highest rates of secretion compared to E1 and E3. The lower panel shows an increase in the amount of labelled protein secreted between E7 and $\mathrm{E} 7+6 \mathrm{~h}$ and a decrease from $\mathrm{E} 7+6 \mathrm{~h}$ to $\mathrm{E} 7+10 \mathrm{~h}$ with a peak in secretion at E7+6h. Note that the period from $\mathrm{E} 5$ to $\mathrm{E} 7+6 \mathrm{~h}$ corresponds to 66 to $74 \mathrm{~h}$ in Figure 1A when the first set of DNA puffs was active. 


\section{SDS-PAGE characterization of secretory proteins}

Figure 2A shows a fluorogram from an SDS-PAGE of labelled secretory polypeptides (SP) as a function of age, with their apparent molecular mass reported as units of $\mathrm{kDa}$. A schematic diagram of this fluorogram is presented in Figure 2B in which the relative quantities of the labelled polypeptides are indicated by the height of the bar. It is clear that specific proteins were secreted at different stages of development. Some polypeptides, such as the 93-kDa polypeptide (SP93), were secreted for short periods of time, i.e., the 4-h period between $\mathrm{E} 7+2 \mathrm{~h}$ and $\mathrm{E} 7+6 \mathrm{~h}$, whereas others such as SP2 1 and SP41 were secreted during the entire 74-h period from E1 to E7+6h. Although less radioactive protein was secreted during $\mathrm{E} 1$ and E3 compared to the later times (Figure $1 \mathrm{~A}$, bottom) at least 3 polypeptides were demonstrable by SDS-PAGE at 21, 41 and $44 \mathrm{kDa}$. Although no quantitative conclusion can be drawn from the data in Figure $2 \mathrm{~A}$, and although not all polypeptides were completely resolved, it is clear that the pattern of labelled secreted polypeptides changed with developmental age and that many of the polypeptides demonstrable during maximum puff activity, i.e., E5 to E7+6h, were not secreted before or after this period. It is important to note that from $\mathrm{E} 7+8 \mathrm{~h}$ to E7+10h only DNA puff B10 was still expanded.

\section{Site of synthesis of new secretory polypeptides}

In Figure 3 we compare the patterns of in vivo polypeptide synthesis in the different salivary gland regions with those of radioactive polypeptides present in the material secreted for a period of $2 \mathrm{~h}$ by larvae of the same age. In these experiments we selected the $\mathrm{E} 1$ age as representative of the very long period of about 8 days during which the
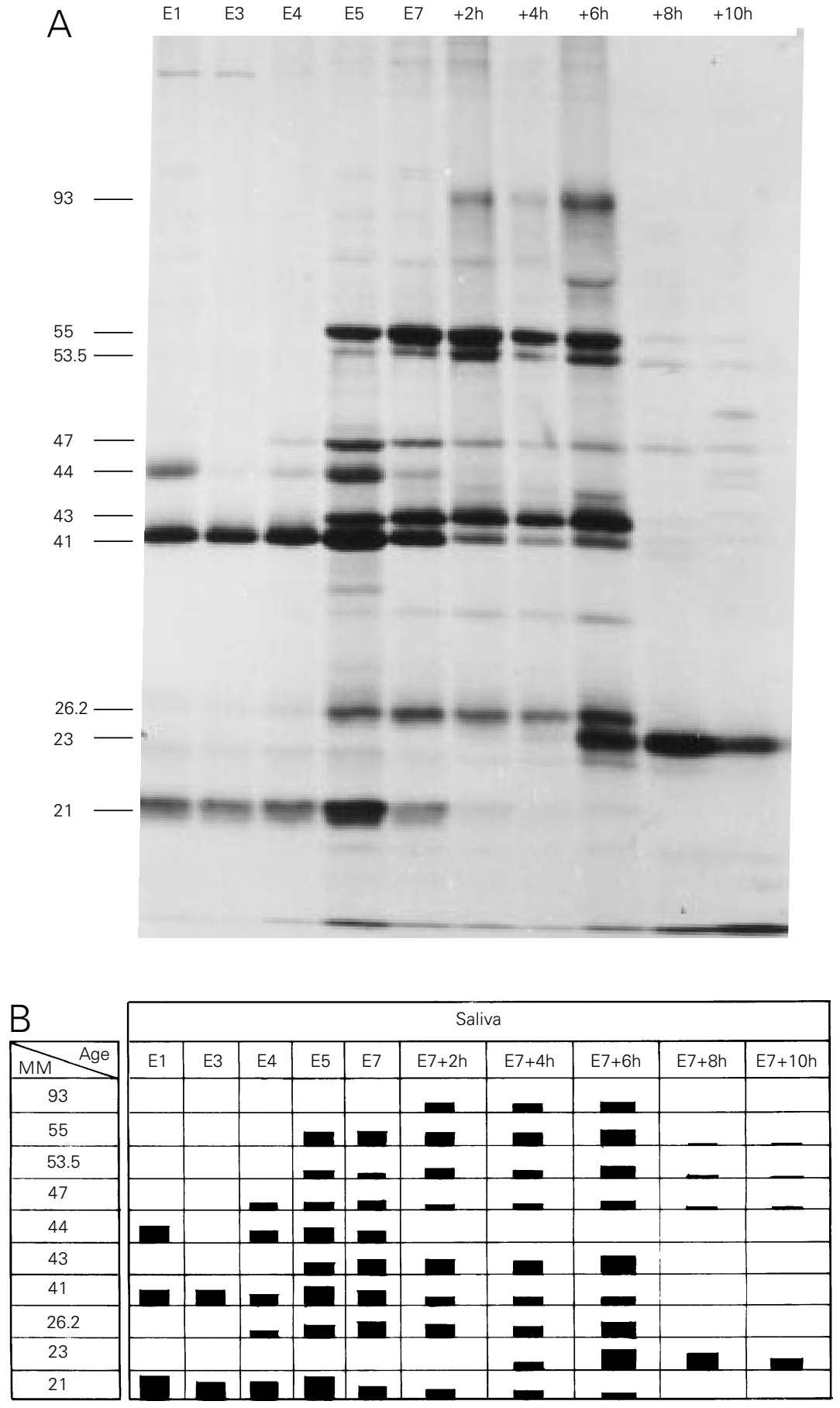

Figure 2 - Patterns of newly synthesized polypeptides present in the saliva of larvae through the end of the fourth instar. Larvae at different ages at the end of the fourth instar were injected with $1 \mu \mathrm{l}$ of $\left[{ }^{3} \mathrm{H}\right]$-Leu solution. The secreted radioactive material was collected over a period of $2 \mathrm{~h}$ from 4 larvae and processed for SDS-PAGE and fluorography (Figure 2A). The ages of the larvae are indicated at the top of each lane. At age E5, the first DNA puffs begin to open and by E7+6h all are already closed, except DNA puff B10. The apparent molecular mass, in $\mathrm{kDa}$, is assigned on the left side. Figure $2 \mathrm{~B}$ presents a schematic diagram of the fluorogram in $2 \mathrm{~A}$. The relative quantities of the labelled polypeptides are indicated by the height of the bars. $\mathrm{MM}=$ Apparent molecular mass in $\mathrm{kDa}$. 
A

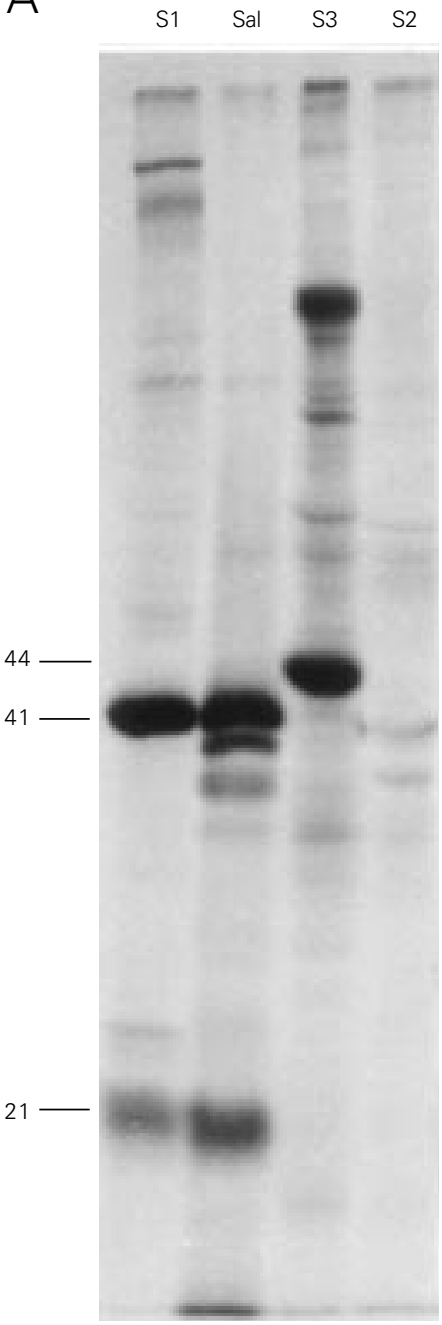

E5

S1 Sal

S3

S2

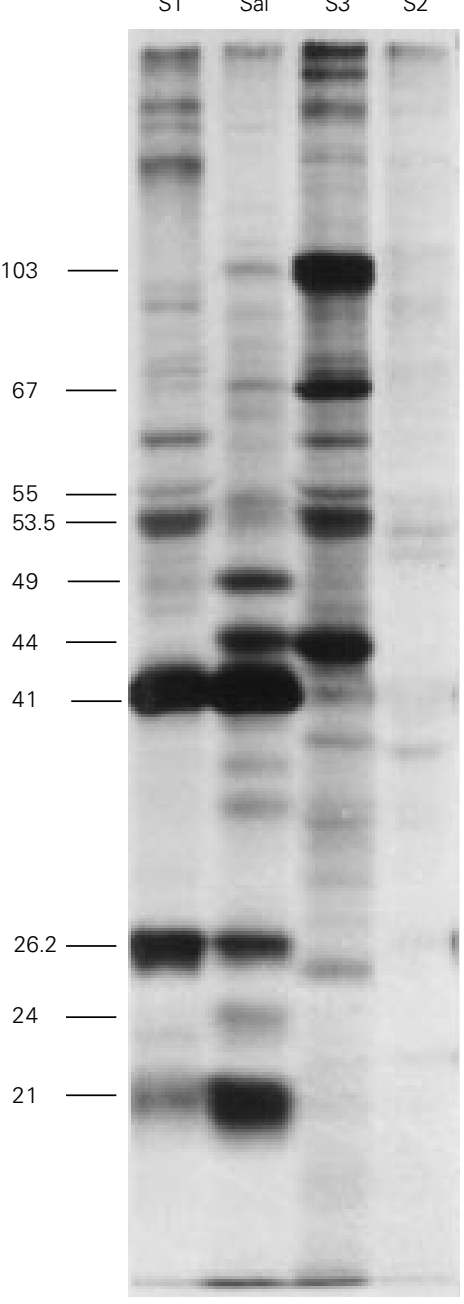

$E 7+6 h$

S1 Sal S3

S2

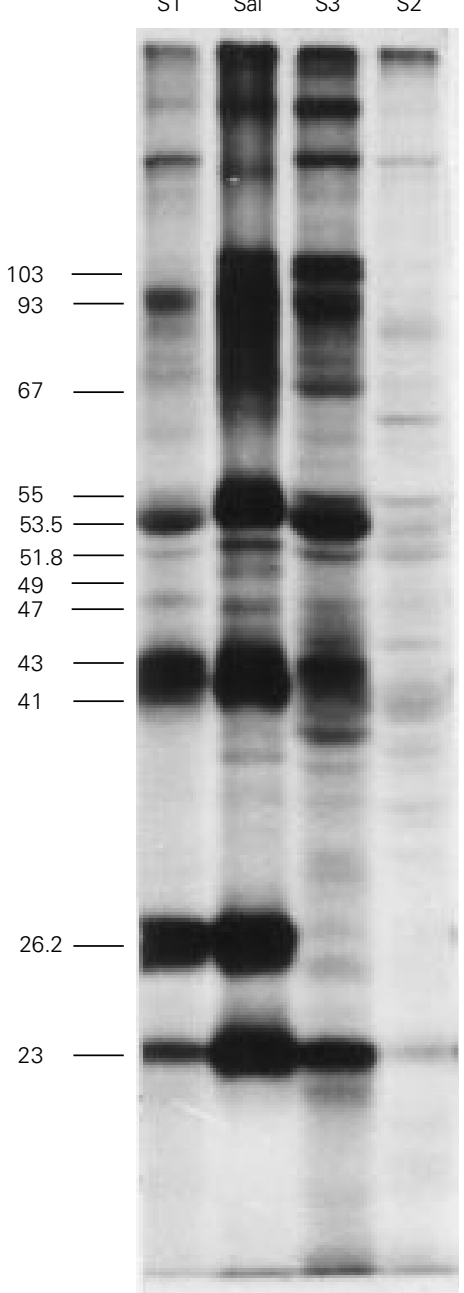

\begin{tabular}{|c|c|c|c|c|c|c|c|c|c|c|c|c|}
\hline B & \multicolumn{3}{|c|}{ Saliva } & \multicolumn{3}{|c|}{ S1 } & \multicolumn{3}{|c|}{ S2 } & \multicolumn{3}{|c|}{ S3 } \\
\hline $\mathrm{MM}$ Age & E1 & E5 & $\mathrm{E} 7+6 \mathrm{~h}$ & E1 & E5 & $\mathrm{E} 7+6 \mathrm{~h}$ & E1 & E5 & $\mathrm{E} 7+6 \mathrm{~h}$ & E1 & E5 & $\mathrm{E} 7+6 \mathrm{~h}$ \\
\hline 103 & & & & & & & & & & & & \\
\hline 93 & & & & & & & & & & & & \\
\hline 55 & & & & & & & & & & & & \\
\hline 53.5 & & & & & & & & & & & & \\
\hline 47 & & & & & & & & & & & & \\
\hline$\overline{44}$ & & & & & & & & & & & & \\
\hline 43 & & & & & & & & & & & & \\
\hline 41 & & & & & & & & & & & & \\
\hline 26.2 & & & & & & & & & & & & . \\
\hline 23 & & & & & & & & & & & & \\
\hline 21 & & & & & & & & & & & & \\
\hline
\end{tabular}

Figure 3 - Fluorographic pattern from the electrophoretic profile of extracts of salivary gland regions (S1, S3 and S2 and saliva (Sal) from larvae of different ages at the end of the fourth instar (E1, E5 and E7+6h). One $\mu$ l of [ $\left.{ }^{3} \mathrm{H}\right]$-Leu solution was injected into the larvae and the salivary gland regions were processed 15 min later for SDS-PAGE and fluorography. Figure 3A shows the same samples compared with samples of saliva collected for $2 \mathrm{~h}$ from larvae of the same ages. The apparent molecular mass, in kDa, of the main SP is indicated on the left side of each set of samples. Figure 3B is a schematic representation of the fluorogram in Figure 3A. The height of the bars represents the relative quantities of the labelled polypeptides. $\mathrm{MM}=$ Apparent molecular mass in $\mathrm{kDa}$. 
same set of polypeptides is synthesized. E5 and E7+6h were chosen because they mark the beginning and the end, respectively, of DNA puffs $\mathrm{C} 7, \mathrm{C} 5$ and $\mathrm{C} 4$ expansion (DNA puff B10 attains its maximum size at E7+8h). Previous experiments (25-27) have demonstrated that the profile of polypeptides synthesized by the salivary gland of Bradysia hygida is essentially the same whether the incorporation of a radioactive precursor is carried out in vivo or in vitro, with incubation times up to $1 \mathrm{~h}$. Using a shorter time of $\left[{ }^{3} \mathrm{H}\right]$-Leu in vivo incorporation (15 $\left.\mathrm{min}\right)$ we assumed that a polypeptide detected in a salivary gland region was synthesized there. Figure 3 summarizes the results obtained in one of several experiments.

In the fluorogram (Figure 3A) the presence of an SP in a sample of saliva is indicated by its approximate molecular mass in $\mathrm{kDa}$, and the presence of polypeptides of similar mobility in salivary gland regions $\mathrm{S} 1$, S3 and S2 can be easily observed. In Figure 3B we show an interpretation of the results presented in Figure 3A. The height of the bars represents a visual measure of labelling intensity. SP21 was present in the saliva of E1 and E5 larvae, since it was detected in the $\mathrm{S} 1$ region at the same ages. SP23 was only present in the saliva at $\mathrm{E} 7+6 \mathrm{~h}$, when it was observed in the three regions, but as a very faint band in $\mathrm{S} 2$.

SP26.2 appeared in the saliva of E5 and E7+6h larvae, and at the same ages was found exclusively in the S1 region. SP41 was present in all saliva samples and was produced by S1. SP43 was present in saliva and in the $\mathrm{S} 1$ and $\mathrm{S} 3$ regions at the age E7+6h. In this experiment SP44 was present only in saliva at E5, whereas in others it was detected also at E1. At E1 and E5 it was present in S3. SP47 and SP23 were present in saliva only at E7+6h and were produced by the three regions at the same age. SP53.5 and SP55 were present in increasing amounts in saliva at ages E5 to E7+6h, and the same occurred in regions S1 and S3. In S2 the amount detected was very low for both polypeptides. SP93 was present in saliva, and S1 and S3 at E7+6h. SP103 was initially detected in saliva at E5 and in larger amounts at E7+6h, and was present only in the S3 region at the same ages. Since the glands have a common duct, although the time of incorporation was short, it is possible that polypeptides detected in the $\mathrm{S} 2$ regions may represent material in transit from $\mathrm{S} 3$ to be secreted in the exterior. Some faint bands only present in the salivary gland regions and probably representing non-secretory proteins were not indicated in the figure. The present results show that SP synthesis can be time and gland region specific.

\section{Discussion}

In the present study we demonstrated an increase in the production and secretion of proteins by the salivary glands of Bradysia hygida during a short period of time, when the first group of DNA puffs is active in the $\mathrm{S} 1$ and $\mathrm{S} 3$ regions. In the $\mathrm{S} 2$ region, where no DNA puffs develop, the level of protein synthesis was very low.

From age E5 to E7+6h, a period of about $8 \mathrm{~h}$, a set of 3 very large DNA puffs started and terminated its morphological expansion. Two of these puffs, $\mathrm{C} 4$ and $\mathrm{C} 5$, were present in the polytene chromosomes of salivary gland regions $\mathrm{S} 1$ and $\mathrm{S} 3$, and the third puff, C7, was present exclusively in S1. At about E7+4h a new DNA puff, B10, started its expansion in regions $\mathrm{S} 1$ and $\mathrm{S} 3$, and at E7 $+12 \mathrm{~h}$ it had already receded. None of these puffs were detected in the S2 region $(14,20)$. It is important to emphasize these observations, because the large increase in the amount of protein material secreted by the larvae and the synthesis of new polypeptides present in this material were accompanied by the synthesis of polypeptides of similar molecular weight mainly in salivary gland regions $\mathrm{S} 1$ and $\mathrm{S} 3$ during the period from age E5 to E7+6h. Here, we assume that the pres- 
ence of a polypeptide of a molecular weight similar to that of the SP in a salivary gland region indicates its site of synthesis because the incorporation time was short (15 min). It has been shown that the pattern of polypeptide synthesis in the salivary gland is essentially the same in vivo and in vitro with incubation times up to $1 \mathrm{~h}$ (25-27).

Our findings are in agreement with the proposition about the role of gene amplification in gene expression (2), i.e., some polypeptides may be necessary in large amounts during a short period of time followed by changes in the program of protein synthesis.

This result can only be attained by the increase in the copy number of genes involved in that event and the use of shortlived mRNAs. This is exactly what we have here: at least for DNA puffs $\mathrm{C} 4$ and $\mathrm{B} 10$ the extent of amplification was established for DNA sequences that code for mRNA to be about 22 and 10 times, respectively (6-9). A large increase in protein production and secretion was detected at the time the DNA puffs were active, with a peak of about 28 times at age E7+6h (Figure 1). The pattern of polypeptide synthesis changed drastically at that time and after about $10 \mathrm{~h}$ the synthesis of most of the polypeptides characteristic of this period stopped completely (Figure 2).

Other results support a very strict temporal correlation between DNA puffs and polypeptide synthesis: in Bradysia hygida the eyespot pattern E7 is reached about $68 \mathrm{~h}$ after E1 (14). If larvae at E1 are injected with a solution of ecdysone, the E7 pattern is attained about $24 \mathrm{~h}$ later and brings about the development of the first group of DNA puffs typical of E7 (28). The induction of DNA puffs by ecdysone is accompanied by the onset of a pattern of polypeptide synthesis similar to that characteristic of E7 (29). Another type of indirect evidence can be obtained by an inverse procedure: it is possible to inhibit DNA puff development by the use of different drugs such as hydroxyurea (20), bromodeoxyuridine (30) and dihydroimidazopyrazole (31), when they are applied to the larvae at the appropriate time. The inhibition of DNA puff development is accompanied by a strong decrease in the synthesis of some of the polypeptides whose production is characteristic of the period of activity of DNA puffs C7, C5, C4 and B10 $(14,32)$. These treatments produce results on the synthesis of specific polypeptides that mimic those characteristic of the ocelliless mutant of Drosophila melanogaster (1).

All these results indicate a role of the first group of DNA puffs in the production by the $\mathrm{S} 1$ and S3 regions of massive amounts of proteins that are secreted and used to spin the larval cocoon, but it cannot be excluded that minor products, destined to stay in the cells, may have regulatory functions.

It is important to note that the contribution of the $\mathrm{S} 2$ region, where the first group of DNA puffs is missing, is negligible in the production of the salivary components described here. However, it was shown that S2 produces and secretes special acid phosphatases that may play an important role in the polymerization of the cocoon protein meshwork (33).

Our results permit additional discussion and speculations: the large number of new polypeptides, whose synthesis is strongly decreased when DNA puff development is inhibited by treatment that apparently does not change RNA puff activity (14,32 and data not shown), compared to the number of DNA puffs suggests that DNA puffs can accommodate more than one gene. This has already been shown for genes II/9-1 and II/92 in DNA puff II/9A of Sciara coprophila (17) and for DNA puff C4 of Bradysia hygida, which contain at least two genes that are amplified unequally and differentially expressed (8).

It is also important to point out the presence of two polypeptides of low molecular weight (SP26.2 and SP23) which were not resolved in previous studies. Their synthesis 
follows very closely the activity of DNA puffs $\mathrm{C} 7$ and B10, respectively. Puff C7 is the first to open and is present exclusively in the $\mathrm{S} 1$ region, as is also the case for SP26.2. Synthesis of SP26.2 continues for about $5 \mathrm{~h}$ after puff $\mathrm{C} 7$ has receded. The SP23 polypeptide is first detected at about $\mathrm{E} 7+4 \mathrm{~h}$, during the expansion of puff B10. At this time a 1.3$\mathrm{kb}$ mRNA is being produced by gene $B h B 10$ $(7,34)$. Maximum puff expansion occurs concurrently with the higher production of 1.3kb mRNA (35) and SP23. SP23 synthesis is very low at about $\mathrm{E} 7+14 \mathrm{~h}$, some $4 \mathrm{~h}$ after puff regression $(36,37)$. By this time the level of B10 messenger has decreased significantly (34). Interestingly additional information on B10 has been presented by Fontes (34), who deduced the amino acid sequence of the B10 polypeptide (PB10) from the sequence of the $B h B 10 \mathrm{cDNA}$. This polypeptide is $17.7 \mathrm{kDa}$, seems to be hydro- phobic, has a presumptive signal peptide and the only two methionine residues in its sequence are eliminated when the signal peptide is cleared. Except for the differences in molecular weight, these features are compatible with PB10 and SP23 being the same polypeptide. Post-translational modifications such as phosphorylation, for example, may be responsible for the fact that SP23 migrates at a higher molecular weight position on SDS-PAGE.

\section{Acknowledgments}

I thank L.A.M. de Andrade and C.R. Marangheti for their dedicated technical assistance. I am grateful to Mr. Mário Castania for preparing the figures, and to Dr. M.L. Paçó-Larson, Dr. E.M.Laicine and Dr. R.G.P. Ramos for critical readings of the manuscript.

\section{References}

1. Breuer ME \& Pavan C (1955). Behavior of polytene chromosomes of Rhynchosciara angelae at different stages of larval development. Chromosoma, 7: 371-386.

2. Spradling AC \& Mahowald AP (1980). Amplification of genes for chorion proteins during oogenesis in Drosophila melanogaster. Proceedings of the National Academy of Sciences, USA, 77: 1096-1100

3. Glover DM, Zaha A, Stocker AJ, Santelli RV, Pueyo MT, de Toledo SM \& Lara FJS (1982). Gene amplification in Rhynchosciara salivary gland chromosomes. Proceedings of the National Academy of Sciences, USA, 79: 2947-2951.

4. Millar S, Hayward D, Read CA, Browne MJ, Santelli RV, Vallejo FG, Pueyo MI, Zaha A, Glover DM \& Lara FJS (1985). Segments of chromosomal DNA from Rhynchosciara americana that undergo additional rounds of DNA replication in the salivary gland DNA puffs have weak activity in yeast. Gene, 34: 81-86.

5. Wu N, Liang C, Di Bartolomeis SM, Smith HS \& Gerbi SA (1993). Developmental progression of DNA puffs in Sciara coprophila: amplification and transcription. Developmental Biology, 160: 73-84.
6. Paçó-Larson ML, Almeida JC de, Edström J-E \& Sauaia H (1992). Cloning of a developmentally amplified gene sequence in the DNA puff C4 of Bradysia hygida (Diptera, Sciaridae) salivary glands. Insect Biochemistry and Molecular Biology, 25: 439-446.

7. Fontes AM, Almeida JC de, Edström J-E \& Paçó-Larson ML (1992). Cloning of a B10 DNA puff sequence developmentally amplified and expressed in the salivary gland of Bradysia hygida. Brazilian Journal of Medical and Biological Research, 25: 777-780.

8. Coelho PSR, Monesi N, Almeida JC de, Toledo F, Buttin G \& Paçó-Larson ML (1993). DNA puff C4 of Bradysia hygida (Diptera, Sciaridae) contains genes unequally amplified and differentially expressed during development. Chromosome Research, 1: 121-126.

9. Monesi N, Fernandez MA, Fontes AM, Basso Jr LR, Nakanishi Y, Baron B, Buttin G \& Paçó-Larson ML (1995). Molecular characterization of an $18 \mathrm{~kb}$ segment of DNA puff C4 of Bradysia hygida (Diptera, Sciaridae). Chromosoma, 103: 715-724.
10. Winter CE, de Bianchi AG, Terra WR \& Lara FJS (1977). Relationships between newly synthesized proteins and DNA puff patterns in salivary glands of Rhynchosciara americana. Chromosoma, 61: 193206.

11. Winter $C E$, de Bianchi AG, Terra WR \& Lara FJS (1977). The giant DNA puffs of Rhynchosciara americana code for polypeptides of the salivary secretion. Journal of Insect Physiology, 23: 1455-1459.

12. De Toledo SM \& Lara FJS (1978). Translation of messages transcribed from DNA puffs of Rhynchosciara. Biochemical and Biophysical Research Communications, 85: 160-166.

13. Winter CE, de Bianchi AG, Terra WR \& Lara FJS (1980). Protein synthesis in the salivary glands of Rhynchosciara americana. Developmental Biology, 75: 1-12.

14. Laicine EM, Alves MAR, Almeida JC de, Rizzo E, Albernaz WC \& Sauaia H (1984). Development of DNA puffs and patterns of polypeptide synthesis in the salivary glands of Bradysia hygida. Chromosoma, 89: $280-284$ 
15. Amabis JM (1980). Biologia dos cromossomos politênicos: seu papel na diferenciação celular. Abstracts of the // Congresso Brasileiro de Biologia Celular, Rio de Janeiro, 23 a 27 de julho, 28-29.

16. Frydman HM, Cadavid EO, Yokosawa J, Silva FH, Navarro-Cattapan LD, Santelli RV, Jacobs-Lorena M, Graessmann M, Graessmann A, Stocker AJ \& Lara FJS (1993). Molecular characterization of the DNA puff C-8 gene of Rhynchosciara americana. Journal of Molecular Biology, 233: 799-803.

17. Di Bartolomeis SM \& Gerbi SA (1989). Molecular characterization of DNA puff II/ 9A genes in Sciara coprophila. Journal of Molecular Biology, 210: 531-540.

18. Sauaia H \& Alves MAR (1968). A description of a new species of Bradysia (Diptera, Sciaridae). Papéis Avulsos de Zoologia, 22: 85-88.

19. Gabrusewicz-Garcia N (1964). Cytological and autoradiographic studies in Sciara coprophila salivary chromosomes. Chromosoma, 15: 312-344.

20. Sauaia H (1971). Cromossomas politênicos de Bradysia hygida - Inibição do desenvolvimento dos pufes de DNA pela hidroxiuréia. Doctoral thesis, Faculdade de Medicina de Ribeirão Preto, Universidade de São Paulo

21. Paçó-Larson ML (1976). Análise quantitativa do conteúdo de DNA da glândula salivar de Bradysia hygida. Master's thesis, Faculdade de Medicina de Ribeirão Preto, Universidade de São Paulo.

22. Sauaia $H$, Laicine $E M$ \& Alves MAR (1971). Hydroxyurea-induced inhibition of DNA puff development in salivary gland chromosomes of Bradysia hygida. Chromosoma, 34: 129-151.

23. Laemmli UK (1970). Cleavage of structural proteins during assembly of the head of bacteriophage T4. Nature, 227: 680685 .
24. Laskey RA \& Mills AD (1975). Quantitative film detection of ${ }^{3} \mathrm{H}$ and ${ }^{14} \mathrm{C}$ in polyacrylamide gels by fluorography. European Journal of Biochemistry, 56: 335341.

25. Almeida JC de, Coelho PSR \& Carvalho DP de (1992). The cells of the S1 region of the salivary gland of Bradysia hygida (Diptera, Sciaridae) can start and sustain, in vitro, a program of protein synthesis. Abstracts of the XXI Reunião Anual da $S B B q$, Caxambu, 75

26. Carvalho DP de \& Almeida JC de (1994). The in vitro effect of ecdysone on gene activity in the $\mathrm{S} 1$ region of $B$. hygida salivary gland. Abstracts of the XXIII Reunião Anual da SBBq, Caxambu, 31

27. Carvalho DP de (1995). Efeito da 20-OH ecdisona in vitro sobre a expressão gênica nas células da região anterior da glândula salivar de Bradysia hygida (Diptera, Sciaridae), durante o quarto estádio larval. Master's thesis, Faculdade de Medicina de Ribeirão Preto, Universidade de São Paulo.

28. Fontes AM \& Paçó-Larson ML (1988) Efeito da ecdisona sobre o desenvolvimento dos pufes de DNA na glândula salivar de Bradysia hygida. Ciência e Cultura, 40 (Suppl): 768 (Abstract).

29. Carvalho DP de \& Almeida JC de (1993). Effect of ecdysone in the induction of a pattern of protein synthesis in B. hygida salivary gland. Abstracts of the XXII Reunião Anual da SBBq. Caxambu, 27.

30. Almeida JC de (1978). Efeito da 5bromodesoxiuridina sobre o desenvolvimento dos pufes de DNA dos cromossomos politênicos da região anterior da glândula salivar de Bradysia hygida (Diptera, Sciaridae). Doctoral thesis, Faculdade de Medicina de Ribeirão Preto, Universidade de São Paulo.

31. Ribeiro WR (1975). Efeito do 2,3 dihidro$1 \mathrm{H}$ imidazo $(1,2-\mathrm{b})$ pirazol (IMPY) sobre o desenvolvimento dos pufes de DNA de Bradysia hygida. Master's thesis, Faculdade de Medicina de Ribeirão Preto, Universidade de São Paulo.
32. Laicine EM, Alves MAR, Almeida JC de, Albernaz WC \& Sauaia H (1982). Expressão gênica no desenvolvimento da glândula salivar de Bradysia hygida. Significado biológico dos pufes de DNA. Ciência e Cultura, 34: 488-492.

33. Laicine EM, Fernandez MA \& Sauaia $H$ (1991). Acid phosphatase activity in mature secretory granules of the salivary gland of Bradysia hygida. Journal of Morphology, 208: 247-255.

34. Fontes AM (1996). Clonagem e caracterização da estrutura e expressão de um gene amplificado no pufe de DNA B10 de Bradysia hygida (Diptera, Sciaridae). Doctoral thesis, Faculdade de Medicina de Ribeirão Preto, Universidade de São Paulo.

35. Almeida JC de, Sousa JF, Valente V \& Silva A de A (1994). The $1.1 \mathrm{~kb}$ transcript from DNA puff B10 of Bradysia hygida salivary gland cells is probably formed by a gradual shortening of the $1.3 \mathrm{~kb}$ RNA species. Abstracts of the XXIII Reunião Anual da $S B B q$, Caxambu, 32.

36. Almeida JC de (1989). The relation between the DNA puff B10 and the production of a salivary polypeptide of $25 \mathrm{kDa}$ in the salivary gland of Bradysia hygida (Diptera, Sciaridae). Abstracts of the XVIII Reunião Anual da SBBq, Caxambu, Arquivos de Biologia e Tecnologia, 32: 26.

37. Barros $\mathrm{HCH}$, Conacci ME \& Almeida JC de (1994). More about the correlation between DNA puff B10 activity and the production of a secretory polypeptide (sp25) in the salivary gland of Bradysia hygida (Diptera, Sciaridae). Abstracts of the XXIII Reunião Anual da SBBq, Caxambu, 32. 